Reprod. Nutr. Dévelop., 1983, 23 (2 A), 175-182.

\title{
Protein secretion by the principal cells of mouse epididymis evidenced by in vitro incorporation of tritiated leucine
}

\author{
Marcelle-Anne FAIN-MAUREL, J. P. DADOUNE (*), Françoise JAUZEIN-LEAU \\ Laboratoire de Biologie cellulaire, UER Etudes médicales et biologiques, \\ Université Paris V, 45, rue des Saints-Pères 75270 Paris Cedex 06, France. \\ (*) Laboratoire d'Histologie, Embryologie et Cytogénétique, \\ Faculté de Médecine Broussais Hôtel Dieu et UER Biomédicale des Saints-Pères, \\ 75006 Paris, France.
}

Summary. The in vitro synthesis and secretion of newly formed proteins were investigated in the principal cells of small pieces of the head and body of mouse epididymis inserted into a modified Rose chamber. Our ultrastructural observations revealed that the cells resumed their normal ultrastructural appearance only after $3 \mathrm{~h}$. Therefore, after preliminary 3-hour culture, the pieces were incubated with tritiated leucine at intervals ranging from $5 \mathrm{~min}$ to $6 \mathrm{~h}$. The incorporation of radioactive leucine measured by scintillation counting demonstrated that each of the anatomical segments studied secreted a significant amount of proteins into the culture medium.

\section{Introduction.}

Many previous, high-resolution, autoradiographic studies in mice have shown that radioactive proteins are synthesized in the epididymis after the administration of several tritiated amino acids. The areas of the epididymis studied include the initial segment (Flickinger, 1979), head, body and tail (FainMaurel et al., 1977 ; Dadoune et al., 1978 ; Fain-Maurel et al., 1981 ; Flickinger, 1981). Nevertheless, because of the existence of pinocytotic vesicles and multivesicular bodies in the principal cells it was supposed that labelling was not related only to the in situ elaboration and secretion of proteins, but also to their reabsorption when transported in the epididymal fluid.

The aim of the present work was to investigate the in vitro synthesis and fate of proteins in the principal cells of the head and body of mouse epididymis incubated separately in the presence of tritiated leucine.

\section{Material and methods.}

Culture procedure. - The epididymis of 2-month old mice weighing about $35 \mathrm{~g}$ was removed, dissected and unravelled under a binocular microscope for observation. Pieces of 1-2 $\mathrm{mm}$ were isolated from different well defined regions 
of the head and body (Soranzo et al., 1982), in other words, at the level of lobes 3 and 4 of the head and at the narrow middle part of the body (Fain-Maurel et al., 1981). This nomenclature appears to us to be preferable to that utilized recently by Flickinger (1981) for regions of the mouse epididymis. After $0.1 \%$ collagenase (204 IU/mg, Millipore Corp.) treatment for $15 \mathrm{~min}$ at $31^{\circ} \mathrm{C}$, two pieces of tissue were placed on a silk screen support and inserted into a modified Rose chamber (Goube de Laforest, 1966). Two compartments in this chamber were filled with Eagle's culture medium (MEM $88 \%$, Biomérieux) supplemented with foetal calf serum (12\%), streptomycine $(100 \mu \mathrm{g} / \mathrm{ml})$ and penicillin (100 lU). Eagle's medium was introduced by injecting $1.5 \mathrm{ml}$ per chamber so that the liquid phase of the upper compartment was in contact with a mixture of $5 \%$ $\mathrm{CO}_{2}$ and $95 \%$ air. These chambers were then placed in an incubator at $31^{\circ} \mathrm{C}$.

Morphological technique. - After organ culture ranging between $5 \mathrm{~min}$ and $9 \mathrm{~h}$, the samples were fixed by immersion for $2 \mathrm{~h}$ at $4{ }^{\circ} \mathrm{C}:$ (1) in $1.5 \%$ glutaraldehyde and $3 \%$ paraformaldehyde in $0.2 \mathrm{M} \mathrm{S}$-collidin buffer, rinsed in buffer and post-fixed for $1 \mathrm{~h}$ at $4{ }^{\circ} \mathrm{C}$ in $2 \%$ osmium tetroxide in $0.1 \mathrm{M}$ S-collidin buffer ; (2) in the same fixative containing Ruthenium Red $(0.5 \%)$ (Luft, 1964) ; and $(3)$ in osmium tetroxide according to the technique of Friend and Murray (1965). After passage in ethanols, all the samples were embedded in Epon.

Amino acid incorporation and liquid scintillation counting. - After $3 \mathrm{~h}$ of culture, the medium was replaced by an identical medium without leucine to which $20 \mu \mathrm{Ci}$ of 4 -leucine- ${ }^{3} \mathrm{H}-4.5$ (n) (CEA, Département des Radioéléments, Gifsur-Yvette, France; specific radioactivity : $15 \mathrm{Ci} / \mathrm{mMole}$ ) were added.

After a 15-min pulse and chase in a medium enriched with unlabelled leucine (Calbiochem, grade $A ; 3.79 \mathrm{mg} / \mathrm{ml}$ ), radioactivity was measured on fragments of fresh tissue and in the chase medium at 5, 15 and $30 \mathrm{~min}$ and at 1, 2, 4 and $6 \mathrm{~h}$ after the end of the pulse.

At each time interval after weighing, the pieces of fresh tissue were homogenized in $1 \mathrm{ml}$ of Tris buffer $(0.005 \mathrm{M})-\mathrm{HCl}, \mathrm{pH} 7.5$, enriched with $0.25 \mathrm{M}$ $\mathrm{KCl}$ and $0.005 \mathrm{M} \mathrm{Mg} \mathrm{Cl}$. After centrifugation, the pellets were successively treated twice with $0.1 \mathrm{ml}$ of $4 \mathrm{M}$ perchloric acid and $1 \mathrm{ml}$ of $0.4 \mathrm{M}$ perchloric acid. All supernatants were pooled and the pellets dissolved in $0.5 \mathrm{ml}$ of Soluene. At the end of the pulse and at each time interval, a 1.5-ml aliquot of the chase medium was treated by perchloric acid as described above and the pellets dissolved in $0.5 \mathrm{ml}$ of Soluene.

For the tissue fragments, the radioactivity of the pellets (nucleic acids + proteins) and the supernatants (free amino acids) was measured in a Packard scintillation spectrometer and expressed in $\mathrm{dpm} / \mathrm{mg}$ per $100-\mu \mathrm{l}$ aliquot of each fraction in $5 \mathrm{ml}$ of scintillation liquid (PCS, Packard Instrument).

For the chase medium, only the radioactivity of PCA-precipitable proteins was measured and expressed in $\mathrm{dpm} / \mathrm{ml}$.

At each time interval, the mean and the standard error of the mean were calculated in the epididymal pieces of two animals. The significance between the means was determined by variant analysis. 
Autoradiography. - Autoradiographic controls were made on samples fixed and embedded as mentioned above. After staining in a solution of $1 \%$ toluidine blue, 1- $\mu \mathrm{m}$ thick sections were dipped in 1:2 Ifford $\mathrm{K} 5$ nuclear emulsion (Ilford, Ltd., Essex, UK). After 4 weeks of exposure at $4{ }^{\circ} \mathrm{C}$, the autoradiograms were developed in Kodak $D_{19} B$ for $4 \mathrm{~min}$ at $18{ }^{\circ} \mathrm{C}$ and fixed in $30 \%$ sodium thiosulfate for $10 \mathrm{~min}$.

\section{Results.}

Morphological study in vitro. - The ultrastructural observations of pieces of head and body of epididymis demonstrated two important cytological changes after $15 \mathrm{~min}$ of culture. The principal cells showed expansion and clearing of the apical cytoplasm which was free of organelles, except for small profiles of smooth endoplasmic reticulum. This aspect was similar to the blebs sometimes observed in vivo. Stereocilia persisted on each side of the blebs. Also, the dictyosomes above the nucleus lost their typical organization and appeared as groups of vacuoles of variable diameter. After $1 \mathrm{~h}$ of culture, the changes in the apical cytoplasm regressed (fig. 1), and the dictyosomes resumed their typical aspect after $3 \mathrm{~h}$ of culture (fig. 2).

From 3 to $9 \mathrm{~h}$ of culture, the morphology of the organelles was comparable to that observed in vivo for the principal cells of the head and body. After fixation in Ruthenium Red, it was observed that the intercellular spaces and junctions were normal regardless of the length of culture (fig. 3). After prolonged osmium impregnation, the Golgi apparatus presented a network-like appearance (Rambourg et al., 1977) (fig. 4).

Tritiated leucine incorporation. - After preliminary 3-h culture, the label was introduced into the culture medium. The synthesis and secretion of newly formed protein were then investigated by qualitative autoradiography and scintillation counting.

The distribution of silver grains was examined in the principal cells of the head and body (fig. 5). After 5-min chase, silver grains were scattered uniformly in the nucleus and cytoplasm throughout the epithelium. Up to $15 \mathrm{~min}$, the intensity of the autoradiographic reaction increased in the epithelium without any modification in labelling distribution. During this time, grains appeared in the lumen of the duct. Notable labelling persisted in epithelial cells for a long time after tritiated leucine incorporation. No difference in the radioactivity pattern was ever observed in the principal cells of the head and body.

Radioactivity greatly decreased between 5 and $15 \mathrm{~min}$ in the acid-soluble fraction of homogenates of the head and body (graph 1A, 2A), whereas it increased in tissue proteins (graph $1 \mathrm{~B}, 2 \mathrm{~B}$ ). The subsequent decrease in the radioactivity of these proteins was accompanied by increased labelling of secreted proteins which appeared in the chase medium as soon as $5 \mathrm{~min}$ after the end of the pulse. It should be noted that radioactivity of the chase medium attained a maximum in $1 \mathrm{~h}$ but with a value significantly higher in the head than in the body. The magnitude of labelling was the same in both segments at $6 \mathrm{~h}$ (graph $1 \mathrm{C}, 2 \mathrm{C})$. 

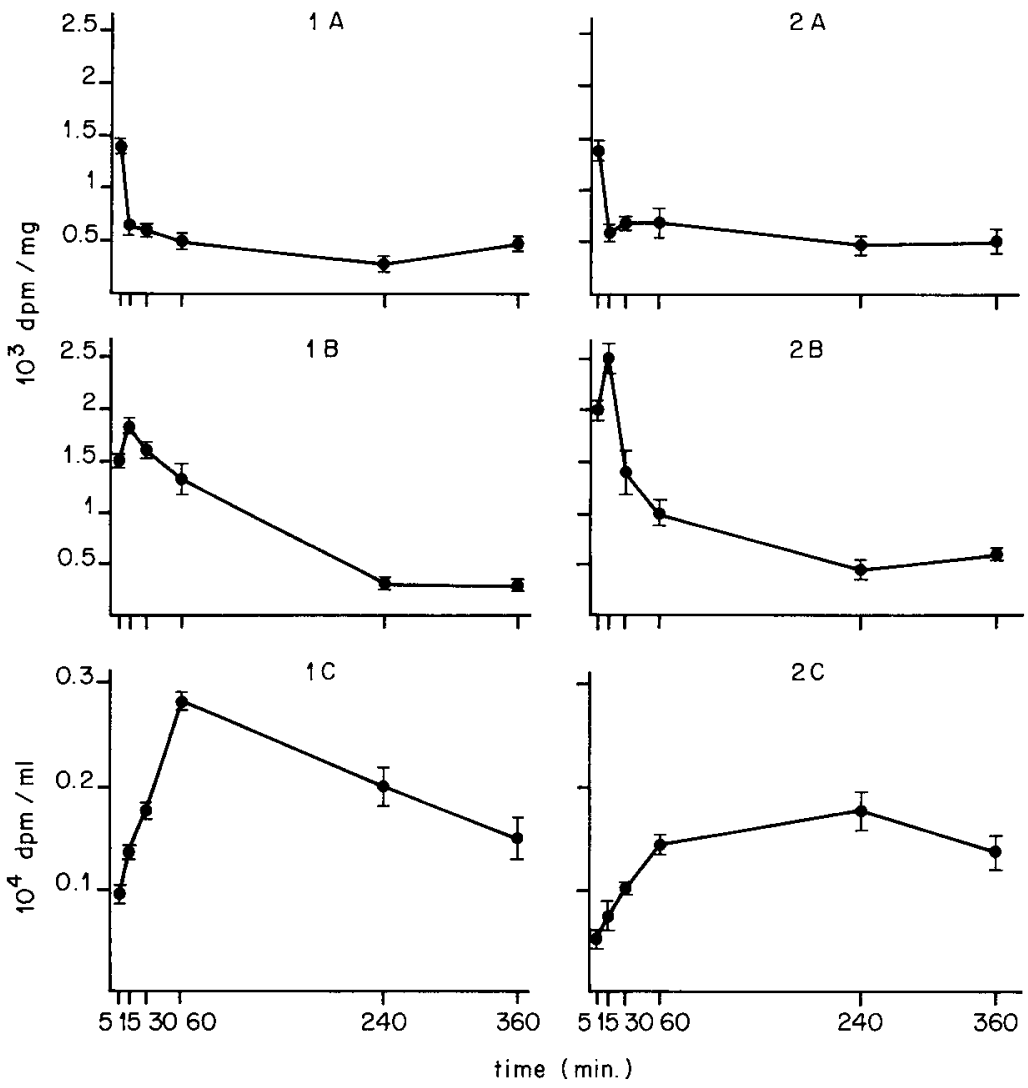

GRAPH. - Radioactivity counts: in the acid-soluble fraction of homogenates of the head $(p>0.025)(1 A)$ and body $(p>0.001)(2 A) ;$ in tissue proteins of the head $(p>0.001)(1 B)$ and body $(p>0.05)(2 B)$; and in the chase medium for the head $(p>0.05)(1 C)$ and body $(p>0.05)$ $(2 \mathrm{C})$.

\section{PLANCHE I}

The morphological and autoradiographic findings in the head and body are the same. The data presented here concern the body.

FIG. 1. - After 15-min culture, the apical protrusion of the cell $\rightarrow \rightarrow$ and the dilatation of Golgi vacuoles $(\mathrm{G})$ are observed. $\times 5000$.

FIG. 2. $-3 h$ later the morphological aspect of the Golgi apparatus (G) is normal. $\times 10200$.

FIG. 3. - Intercellular spaces as evidenced by Ruthenium Red staining without additional staining. $\times 15000$.

FIG. 4. - The network-like aspect of the Golgi apparatus is seen on a 0.5- $\mu \mathrm{m}$ thick section after prolonged osmium impregnation. $100 \mathrm{kv} ; \times 4500$.

FIG. 5. - Thick-section autoradiograms. From the 1st (fig. 5A) to the 4th (fig. 5B) hour of culture, numerous silver grains appear in the lumen. $\times 130$. 

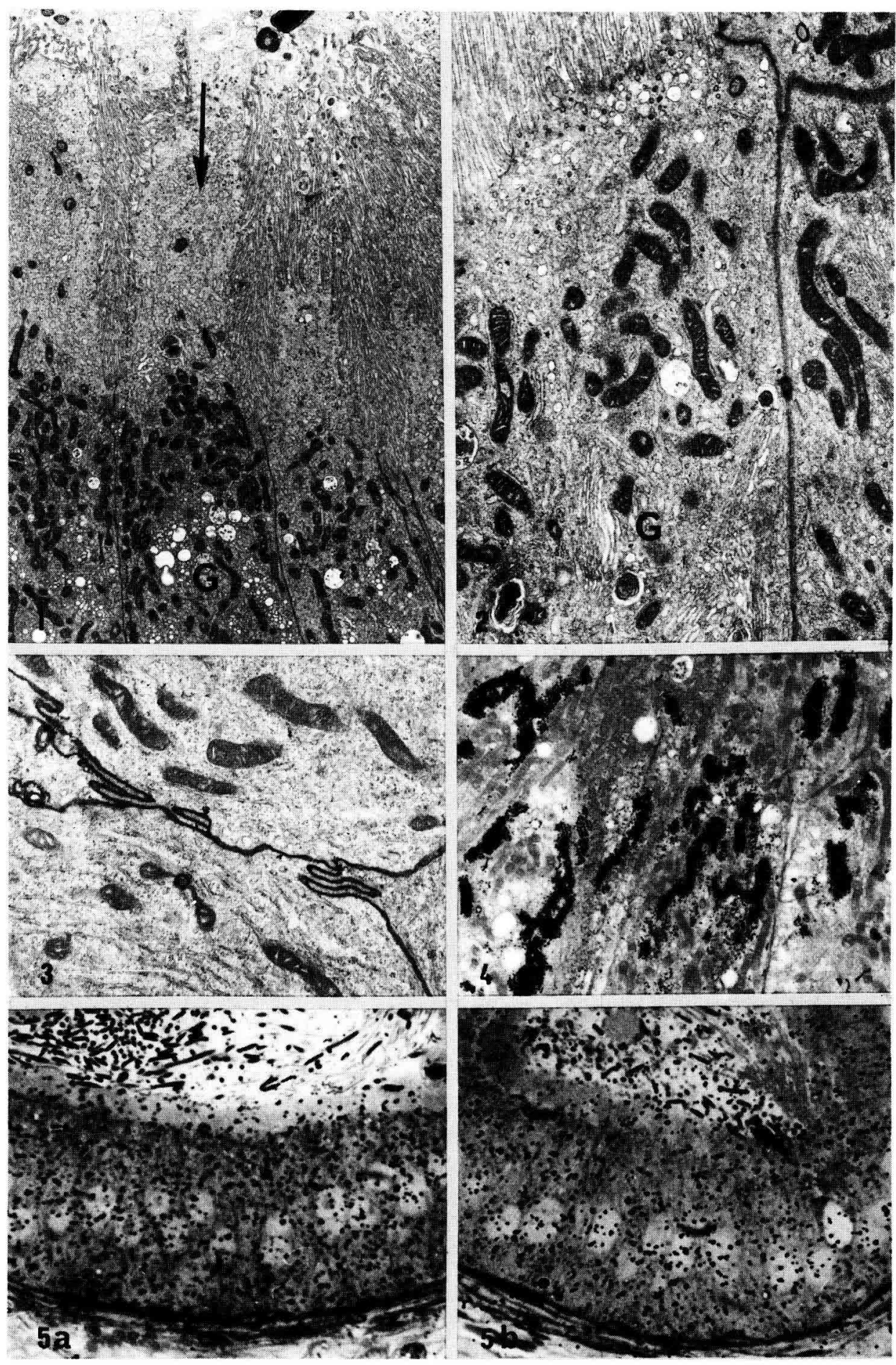


\section{Discussion.}

Electron microscopic observations revealed that the morphological integrity of the explants was not maintained during the first $3 \mathrm{~h}$ of culture, although cellular cohesion and preservation of the plasma membrane never changed. The reversibility of apical alterations (complete after $1 \mathrm{~h}$ of culture) led us to assume that the blebs observed in vivo were an artefact. The time sequence of the reorganization of the dictyosomes indicated that the synthetic ability of the Golgi apparatus of the principal cells did not appear before the 3rd hour of culture. Thus, radioactive precursor incorporation was not tested until after this lapse of time.

Silver grain distribution in the brief interval following the pulse attests to the fact that tracer penetration into the epithelial cells of the head and body was regular and homogeneous. The absence of changes in the intracellular labelling pattern with time is not surprising because identical autoradiographic observations have been made in vivo in the same species (Dadoune et al., 1978 ; FainMaurel et al., 1977, 1981 ; Flickinger, 1979, 1981) but only quantitative study has shown successive variations in the labelling of the different organelles implicated in protein synthesis.

The rapid decrease of radioactivity in the acid-soluble fraction of the homogenates indicates that a highly radioactive pulse occurred in $5 \mathrm{~min}$. From this time, the incorporated radioactivity of the two segments studied was significantly elevated in the chase medium. During in vivo autoradiographic studies, early labelling was also seen in the lumen of the epididymis (Fain-Maurel et al., 1977, 1981 ; Dadoune et al., 1978 ; Flickinger, 1981). In this type of study, despite the usual precautions taken in preparing the tissues for autoradiography, the risk of non-specific adsorption of triatiated amino acids could not be totally excluded because of the high concentrations of free amino acids in the rete testis fluid (Tuck et al., 1970; Shimazaki et al., 1976). The present in vitro investigation totally eliminated this risk and, therefore, demonstrates that protein is secreted in the epididymal fluid.

Evaluation of the radioactivity pattern in tissue proteins and in the chase medium over a period of time clearly reveals that newly synthesized proteins are elaborated and secreted concomitantly in each of the anatomical segments studied. Incorporated radioactivity appeared to be more elevated at $5 \mathrm{~min}$ in tissue proteins of the body than of the head. However, this does not seem to be related to higher synthetic activity but rather to the retention of synthesized proteins since, at that time, labelling in the chase medium was two times higher in the head than in the body. In fact, if one considers the sum of the radioactivity detected in the tissue proteins and in the chase medium, it appears that protein synthesis and secretion are both significantly higher in the head.

In the chase medium, the radioactivity of these two segments of the epididymis reached a maximum in the first hour and then stayed at that significantly elevated level until the end of the experiment. This confirms the duration of secretion demonstrated in previous in vivo studies (Fain-Maurel et al., 1981 ; Flickinger, 1981). On the other hand, in pieces of the body of rabbit epididymis 
maintained in a static culture system as well as in a continuous flow system, labelling only appears in the lumen after $4 \mathrm{~h}$ (Orgebin-Crist and Ménézo, 1980). The difference between the observation of these authors and ours may reflect a species difference, but the culture methods used in the present work appear to have no effect on label incorporation, at least for relatively short culture times.

The upsurge of radioactivity observed in acid-soluble homogenate fractions as well as in tissue proteins at $\mathbf{3 6 0} \mathrm{min}$ corroborates data found in vivo showing an increase in the radioactivity of organelles involved in protein synthesis after the first secretory cycle (Dadoune et al., 1978; Fain-Maurel et al., 1981).

Reçu en mars 1982.

Accepté en octobre 1982.

Acknowledgements. - The authors wish to thank Dr. Reger for his contribution to the translation of the manuscript and Mr. Marchi for his skillful technical assistance.

Résumé. Mise en évidence in vitro de la sécrétion de protéines par les cellules principales de l'épididyme de souris après incorporation de leucine tritiée.

La synthèse et la sécrétion de protéines nouvellement formées ont été étudiées dans les cellules principales de l'épididyme de souris, entre 5 minutes et 6 heures, sur de petits fragments de tête et de corps maintenus en survie dans des chambres de Rose modifiées, puis incubés en présence de leucine tritiée. Les observations ultrastructurales ont révélé que l'aspect normal des cellules n'était restauré qu'après 3 heures de culture. Le taux de radioactivité mesuré en scintillation liquide après ce laps de temps montre l'existence d'une sécrétion significative des protéines dans le milieu de culture pour chacune des portions anatomiques.

\section{References}

DADOUNE J. P., FAIN-MAUREL M. A., ALFONSI M. F., 1978. Radioautographic evidence for protein elaboration and secretion in epididymis epithelial cells. 9th Int. Congr. Electr. Microsc. Toronto, Vol. II, 686.

FAIN-MAUREL M. A., DADOUNE J. P., ALFONSI M. F., 1977. Modalités d'incorporation de l'arginine tritiée dans l'épithélium du canal épididymaire de souris. Biol. cell., 29, 7a.

FAIN-MAUREL M. A., DADOUNE J. P., ALFONSI M. F., 1981. High-resolution autoradiography of newly formed proteins in the epididymis after incorporation of tritiated amino acids. Arch. Androl., 6, 249-266.

FLICKINGER C. J., 1979. Synthesis, transport and secretion of protein in the initial segment of the mouse epididymis as studied by electron microscope radioautography. Biol. Reprod., 20 , 1015-1030.

FLICKINGER C. J., 1981. Regional differences in synthesis, intracellular transport, and secretion of protein in the mouse epididymis. Biol. Reprod., 25, 871-883.

FRIEND D. S., MURRAY M. J., 1965. Osmium impregnation of the Golgi apparatus. Amer. J. Anat., 117, 135-150.

GOUBE DE LAFOREST P., 1966. Description d'une chambre de Rose modifiée pour la culture d'organes en milieu liquide. Exp. Cell Res., 42, 399-403.

LUFT J. H., 1964. Electron microscopy of cells extraneous coats as revealed by ruthenium red staining. J. Cell Biol., 23, 54A. 
ORGEBIN-CRIST M. C., MENEZO Y., 1980. A continuous flow method for organ culture of rabbit epididymis : morphology, amino acid utilization, glucose uptake, RNA, and protein synthesis. J. Androl., 1. 289-298.

RAMBOURG A., CLERMONT Y., MARRAUD A., 1977. Three dimensional structure of the osmium impregnated Golgi apparatus as seen in the high voltage electron microscope. Amer. $J$. Anat., 140, 27-47.

SHIMAZAKI J., YAMANAKA H., TAGUCHI I., SHIDA K., 1976. Free amino acids in the caput and the cauda epididymis of adult rats. Endocrinol. jap., 23, 149-156.

SORANZO L., DADOUNE J. P., FAIN-MAUREL M. A., 1982. La segmentation du canal épididymaire chez la souris. Etude ultrastructurale. Reprod. Nutr. Dévelop., 22, 999-1012.

TUCK R. R., SETCHELL B. P., WAITES G. M. H., YOUNG J. A., 1970. The composition of fluid collected by micropuncture and catheterization from the seminiferous tubules and rete testis of rats. Pflügers Arch., 318, 225-243. 